\section{Postural visual obscurations in patients with inactive thyroid eye disease; a variant of 'hydraulic' disease}

GE Rose

medial wall and floor alone (mean reduction $6.8 \mathrm{~mm}$, range $5-8 \mathrm{~mm}$; four orbits). In all patients, there was an almost immediate cessation of obscurations, together with a subjective and objective improvement in various visual functions. Optic disc swelling resolved over a few weeks after surgery. Conclusion The 'hydraulic' variant of thyroid eye disease - characterised by high orbital apex pressures, with secondarily raised episcleral venous and intraocular pressures - may be linked with certain orbital shapes, such as that of Asians. This variant can present with recurrent visual obscuration associated with transient postural hypotension, especially in diabetics - this possibly being due to a microvasculopathy of the orbital or optic nerve circulation.

Eye (2006) 20, 1178-1185. doi:10.1038/sj.eye.6702381

Keywords: optic neuropathy; orbital decompression; diabetes; thyroid eye disease; visual obscurations

Introduction

Thyroid optic neuropathy arises from tissue crowding in the posterior one-third of the orbit, this typically being due to muscular enlargement, ${ }^{1,2}$ and surgical relief of neuropathy necessitates bone removal and periosteal opening at the orbital apex. ${ }^{1-5}$ Although increased apical pressure will inevitably raise episcleral venous pressure, this is only rarely manifested as episcleral vascular dilation. Some patients with inactive thyroid eye disease and mild proptosis, however, have a markedly increased orbital pressure that can be associated with deep orbital vascular congestion, proptosis reduction of $5.8 \mathrm{~mm}$ (range $2-8 \mathrm{~mm}$; eight orbits) and $2 / 6$ had decompression of the 
persistently raised intraocular pressures and, in some cases, optic neuropathy. ${ }^{2,6}$ This congestive variant - termed 'hydraulic' disease by the writer, to distinguish it from the congestion of the active inflammatory phase - appears commoner with certain races (particularly Asians ${ }^{7,8}$ ), this probably being due to their thicker orbital walls and relatively less compliant orbital septum.

This paper presents a typical case of hydraulic thyroid eye disease, treated effectively with three-wall orbital decompression, and also newly describes the clinical characteristics for a group of such patients presenting with transient visual obscuration during periods of postural hypotension.

\section{Patients and methods}

A retrospective review of clinical records was undertaken for patients presenting with repeated transient visual obscuration in association with inactive thyroid eye disease; the patients being identified from the Orbital Clinic database at Moorfields Eye Hospital.

All patients had full ophthalmic assessment and appropriate orbital imaging. The orbital congestion was treated by orbital decompression, performed through a lower-lid swinging flap approach, with complete removal of the bone and periorbita from the medial wall and the medial half of the orbital floor. Where a greater reduction in proptosis was required, the decompression was extended to include a large window in the lateral orbital wall and additional removal of the floor over, and lateral to, the infraorbital nerve.

\section{Results}

\section{Case reports}

\section{'Hydraulic' thyroid eye disease}

A 68-year-old male presented with 12 months of ocular inflammation, treated with systemic steroids and orbital radiotherapy, the symptoms having increased 3 months prior to referral - with bilateral periocular oedema and slight blurring of vision. Thyrotoxicosis had been medically treated 2 years before and the patient had received radioiodine a year later - with onset of ocular redness, irritability and watering. The patient was referred while taking $80 \mathrm{mg}$ systemic prednisolone daily for his thyroid eye disease, together with topical latanoprost and betaxolol.

The Snellen acuity at referral was 6/6 right and 6/36 left (in a densely amblyopic eye), with normal right Ishihara colour perception and no relative afferent pupillary defect (RAPD). There was no clinical evidence of orbital inflammation, extremes of ocular ductions were


Figure 1 (a) 68-year-old man with inactive thyroid orbitopathy, displaying the features of 'hydraulic', or 'meta-active', disease - with limited ocular ductions in very tight orbits, chronic lid and cheek oedema, and moderate proptosis. (b) Prominent episcleral venous dilatation, due to high pressures at the orbital apex, is frequently misinterpreted as active inflammation and is associated with markedly raised intraocular pressures, despite multiple topical therapy. Orbital CT shows (c) bilateral proptosis with marked vascular engorgement and (d) diffuse enlargement of the recti with high intraorbital pressures - evident as flattening of the back of the globes. 
moderately limited, Hertel exophthalmometry was $27 \mathrm{~mm}$ in each eye, and there were gross cheek festoons of congestive oedema (Figure 1a). Both eyes showed marked episcleral venous congestion and the intraocular pressures on treatment were $19 \mathrm{mmHg}$ right and $23 \mathrm{mmHg}$ left (Figure 1b). Orbital CT demonstrated bilateral proptosis, with diffuse muscular enlargement and vascular congestion (Figure $1 \mathrm{c}$ and $\mathrm{d}$ ).

After bilateral three-wall orbital decompression, episcleral venous congestion disappeared over a few weeks (Figure 2b), intraocular pressures - off all topical medications - returned to normal range, and the gross periocular oedema resolved slowly over a year (Figure 2a).

\section{Case 1}

A 42-year-old male, insulin-dependent diabetic for 12 years, was referred with a 6 month history of irritable, red eyes; a diagnosis of thyrotoxicosis and thyroid eye disease had been made 3 months prior to referral and
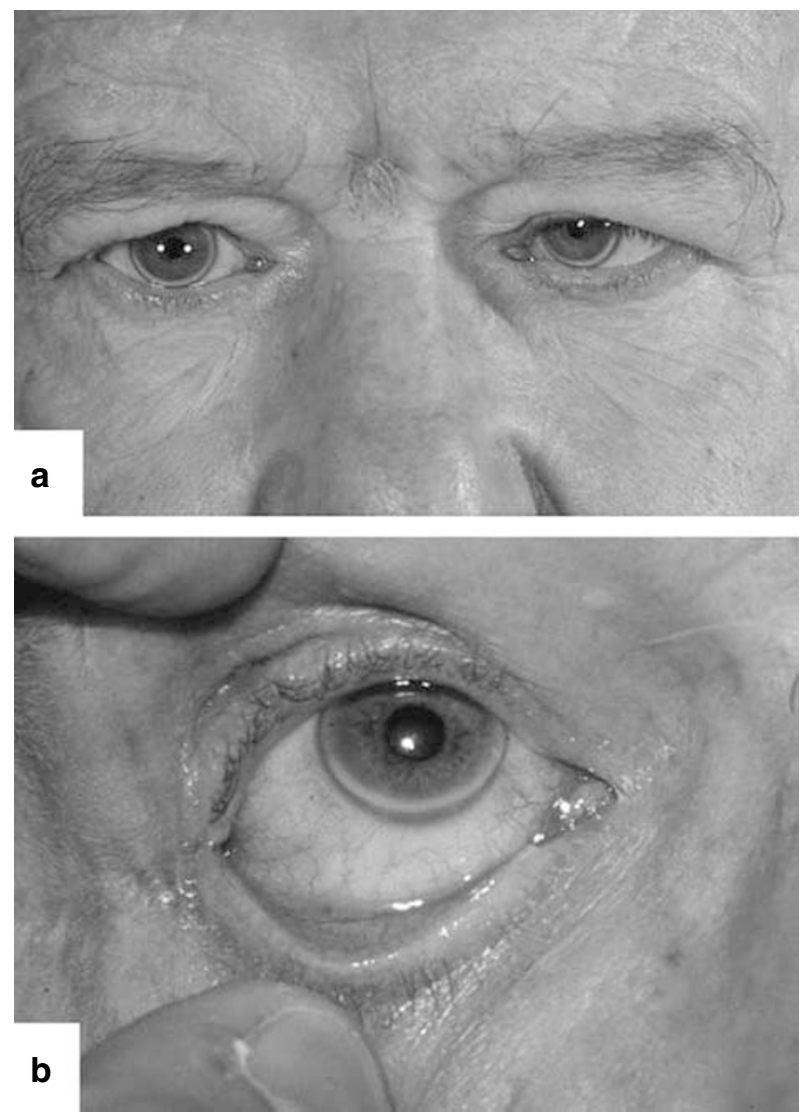

Figure 2 (a) Resolution of the eyelid oedema and malar festoons, for the patient illustrated in Figure 1, at a year after bilateral three-wall orbital decompression. (b) Intraocular pressures were normal, on no treatment, and the episcleral venous congestion had completely resolved. treated with carbimazole, systemic steroids and methotrexate.

His vision had deteriorated over 3 weeks prior to referral, with increasing diplopia, and the patient had noted that the sight in both eyes frequently 'faded out' on getting up from a chair or bed: The visual loss occurred on bending or rapidly changing position, appearing as a rapid 'blacking out' of the visual field, with the eyesight returning after about $15-20 \mathrm{~s}$. The patient had never experienced visual symptoms prior to the onset of thyroid eye disease, and did not have any overt symptoms or signs of systemic hypertension, diabetic vasculopathy or prior postural hypotension and syncope.

The acuity at first referral was Snellen 6/9 right and 6/12 left, with moderately impaired colour perception and a mild left RAPD. Both orbits were extremely tense, with bilateral Hertel exophthalmometry of $23 \mathrm{~mm}$, and there was gross impairment of ocular movements (Figure 3a). The optic discs were markedly swollen (Figure $3 b$ ), the retinal and episcleral veins congested, and the intraocular pressures were $25 \mathrm{mmHg}$ right and $31 \mathrm{mmHg}$ left on downgaze (rising to 43 and $56 \mathrm{mmHg}$ on attempted upgaze).

Although there was an improvement in acuity to 6/9 right and 6/6 left, with disappearance of the left RAPD, after 3 days of systemic methylprednisolone ( $1 \mathrm{~g}$ daily), there was persistence of the gross optic disc swelling and the transient visual obscurations. The patient therefore underwent bilateral three-wall decompression, with complete disappearance of the postural obscurations from the day after surgery, normal Ishihara colour perception within a week, resolution of disc swelling over 3-4 weeks (Figure 4) and disappearance of the episcleral venous congestion (with return of intraocular pressures to normal) over about 6 months.

\section{Case 2}

A nonsmoking 51-year-old diabetic woman (on insulin for 2 years) was referred with an 8 month history of bilateral eyelid swelling treated with systemic steroids and methotrexate; she had thyrotoxicosis, treated with radio-iodine, about 9 months before onset of eye symptoms. For a month prior to referral, the patient had noted transient 'blackouts of vision', occurring in both eyes for several seconds, on rapid standing or on bending.

The patient's acuity at referral was 6/18 right and 6/24 left, with good right and fair left colour perception (Figure 5a). There was moderate exophthalmos (Hertel $25 \mathrm{~mm}$ right, $27 \mathrm{~mm}$ left), orbits that were very resistant to retropulsion, and a gross restriction of eye movements. Intraocular pressures were $30 \mathrm{mmHg}$ right and $28 \mathrm{mmHg}$ left, with a mild rise on attempted upgaze. Bilateral optic 

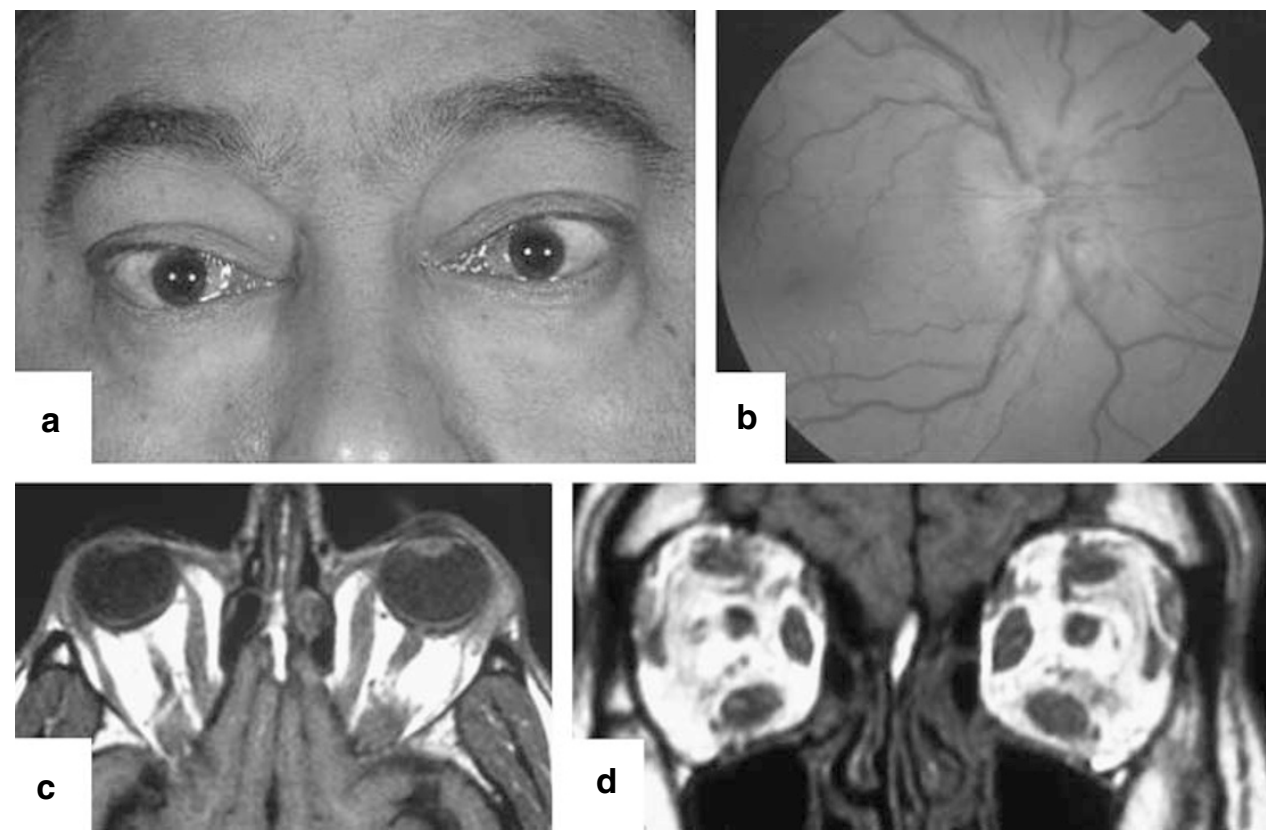

Figure 3 (Case 1) (a) A 42-year-old insulin-dependent diabetic man was referred with a 6-month history of thyroid eye disease and 3 weeks of bilateral postural visual obscurations. Both orbits were very tense, with marked restriction of eye movements, raised intraocular pressures, episcleral venous congestion and grossly swollen optic discs (b). Orbital imaging confirmed moderate proptosis (c) with marked orbital vascular congestion (d).

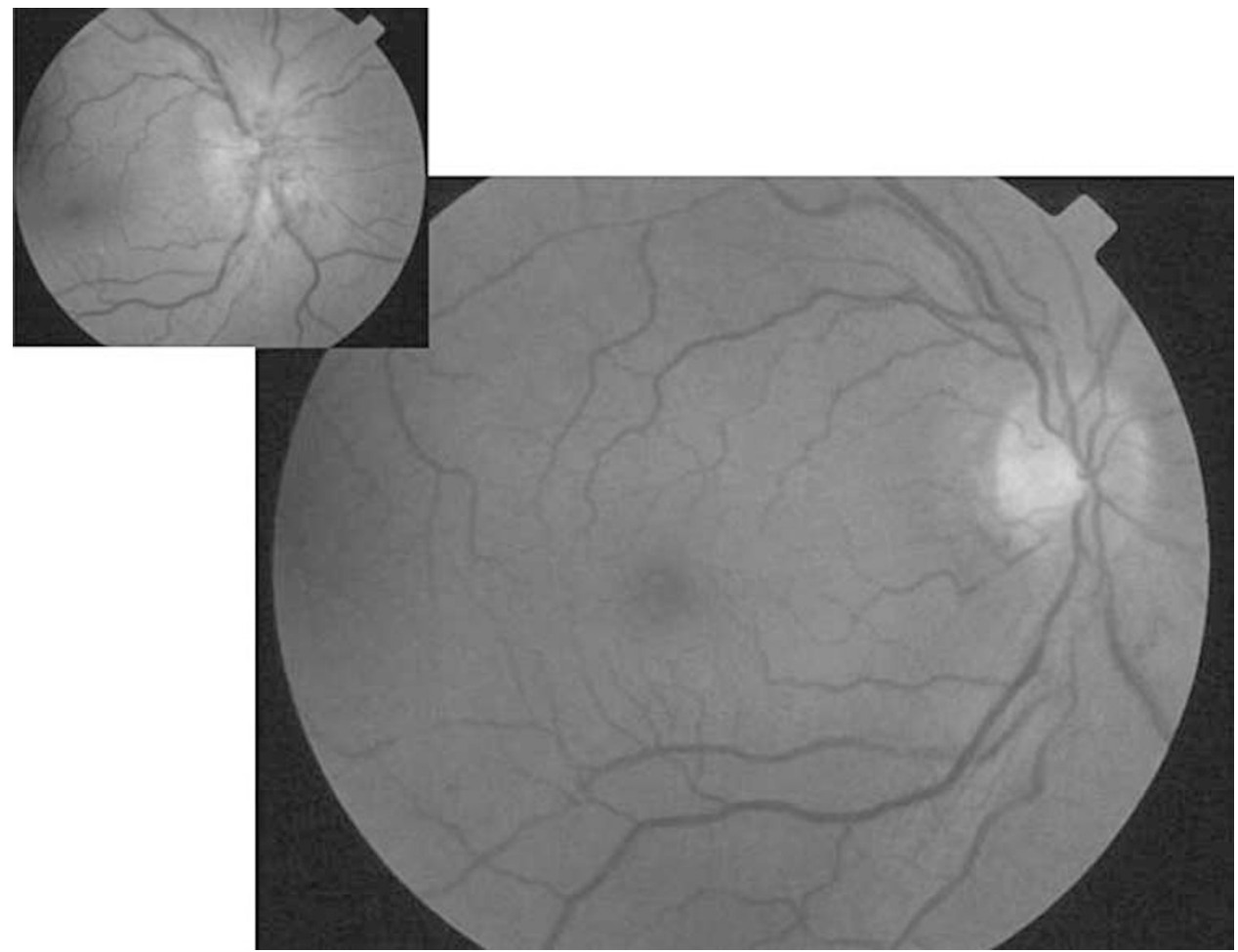

Figure 4 (Case 1) Following bilateral three-wall orbital decompression, there was a gradual resolution of optic disc swelling over 3-4 weeks: Right optic disc at 2 months after surgery, compared with that before decompression (inset). 

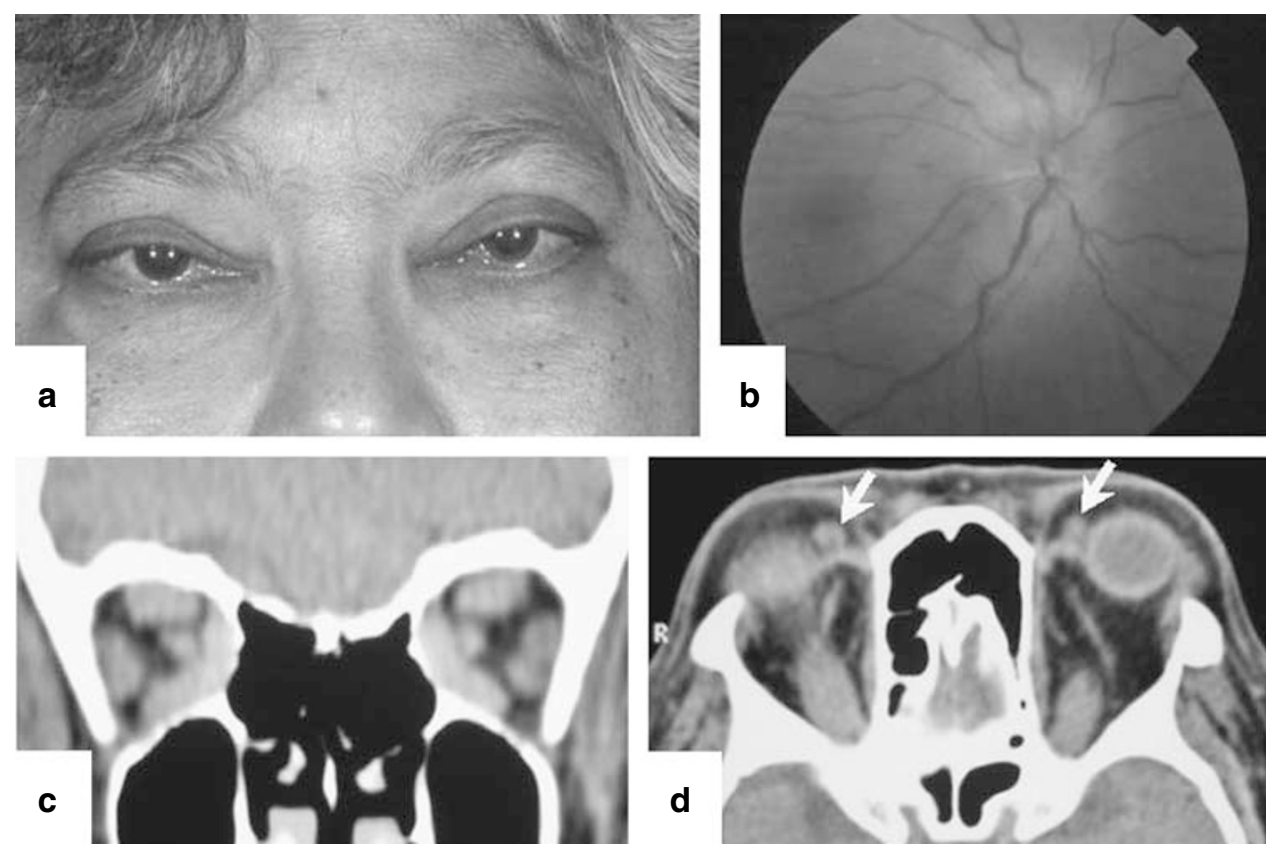

Figure 5 (Case 2) (a) An insulin-dependent diabetic woman of 51 years of age was referred with 8-month history of thyroid orbitopathy and a month of postural visual obscurations. She had extremely tense orbits, with moderate bilateral optic neuropathy and raised intraocular pressures. (b) Bilateral optic disc swelling and choroidal folds were evident. Orbital CT showed (c) grossly enlarged recti compatible with thyroid eye disease and (d) moderate proptosis and gross vascular engorgement (arrows: anterior part of superior ophthalmic veins).

disc swelling and choroidal striae were evident (Figure 5b) and orbital CT showed large recti (Figure 5c) and gross vascular engorgement (Figure $5 \mathrm{~d}$ ).

Three-wall orbital decompression resulted in immediate cessation of visual obscurations and the disc swelling and choroidal folds cleared over 2-3 weeks after surgery; intraocular pressure control remained variable and the left visual acuity remained somewhat reduced due to herpetic kerato-uveitis.

\section{Group characteristics}

Six patients (five female; $83 \%$ ) had recurrent obscuration of vision on sudden changes of posture, these obscurations presenting as a rapid 'blacking out' of visual field with a recovery over $20-30 \mathrm{~s}$. The patients were aged between 43 and 66 years (mean 54.7, median 52 years) and had noticed obscurations for between 3 weeks and 2 months, often in association with a subjective reduction in visual acuity and colour discrimination; all had prior signs and symptoms of active thyroid eye disease for between 6 and 18 months, for which they had received systemic immunosuppression and, in 5/6 cases, topical therapy for moderately or markedly raised intraocular pressures (Table 1). Four of the six patients had thyrotoxicosis, this being only 1-2 years before onset of orbital disease, whereas the $2 / 6$ with primary myxoedema developed the thyroid condition 13 and 24 years before the eye disease (Table 1). Four patients had insulin-controlled diabetes, with the condition for 2, 12, 29, and 45 years, and one had a 2-year diagnosis of diabetes treated with metformin.

The acuity at presentation ranged from $6 / 9$ to counting fingers (Table 1) and all patients had increased orbital tension on clinical assessment; intraocular pressures were raised to the high $20 \mathrm{~s}$ and $30 \mathrm{~s}$ (mmHg) in $5 / 6$ patients - despite multiple therapy. The optic disc was markedly swollen in all affected orbits, with bilateral choroidal folds in two patients, and Hertel exophthalmometry ranged from 22 to $27 \mathrm{~mm}$ (Table 1). There was a global reduction in ocular ductions in all cases.

Bilateral orbital decompression was performed in all patients, although sequentially in one patient: $4 / 6$ patients had three-wall decompression with an average proptosis reduction of $5.8 \mathrm{~mm}$ (range $2-8 \mathrm{~mm}$; eight orbits) and 2/6 had decompression of the medial wall and floor alone (mean reduction $6.8 \mathrm{~mm}$, range $5-8 \mathrm{~mm}$; four orbits) (Table 2). In all patients there was an almost immediate cessation of obscurations, together with a subjective and objective improvement in various visual functions. Optic disc swelling resolved over a few weeks after surgery. 
Table 1 Clinical characteristics for six patients with visual obscurations due to 'hydraulic' thyroid eye disease

\begin{tabular}{|c|c|c|c|c|c|}
\hline $\begin{array}{l}\text { Patient } \\
\text { number }\end{array}$ & $\begin{array}{l}\text { Age at diabetes; } \\
\text { treatment }\end{array}$ & $\begin{array}{l}\text { Diagnosis of thyroid } \\
\text { abnormality; } \\
\text { treatment }\end{array}$ & Medical history & $\begin{array}{l}\text { Age at surgery; } \\
\text { ophthalmic symptoms } \\
\text { and duration }\end{array}$ & Ophthalmic signs \\
\hline 1 (Male) & $\begin{array}{l}30 \text { years of age; } \\
\text { insulin }\end{array}$ & $\begin{array}{l}\text { Thyrotoxic at } 42 \\
\text { years; carbimazole }\end{array}$ & None & $\begin{array}{l}43 \text { years; red, } \\
\text { watery eyes } \\
(6 \text { months), diplopia } \\
\text { ( } 3 \text { months), } \\
\text { obscurations } \\
\text { ( } 3 \text { weeks) }\end{array}$ & $\begin{array}{l}\text { Acuity } 6 / 9 \text { right, } 6 / 12 \text { left; } \\
\text { mild left RAPD, tight orbits } \\
\text { and poor EOM, episcleral } \\
\text { venous engorgement, } \\
\text { markedly raised intraocular } \\
\text { pressures, Hertel } 23 \text { mm each } \\
\text { orbit, gross optic disc swelling }\end{array}$ \\
\hline 2 (Female) & $\begin{array}{l}49 \text { years of age; } \\
\text { insulin }\end{array}$ & $\begin{array}{l}\text { Thyrotoxic at } 50 \\
\text { years; carbimazole } \\
\text { and later radio- } \\
\text { iodine }\end{array}$ & None & $\begin{array}{l}51 \text { years; red, } \\
\text { swollen eyes ( } 8 \\
\text { months), decreased } \\
\text { vision ( } 1 \text { month), } \\
\text { obscurations } \\
\text { (1 month) }\end{array}$ & $\begin{array}{l}\text { Acuity } 6 / 24 \text { both eyes; no } \\
\text { RAPD, tight orbits and poor } \\
\text { EOM, episcleral venous } \\
\text { engorgement, moderately } \\
\text { raised intraocular pressures, } \\
\text { Hertel } 25 \text { mm right, } 27 \text { mm left } \\
\text { orbit, gross disc swelling and } \\
\text { choroidal folds }\end{array}$ \\
\hline 3 (Female) & $\begin{array}{l}6 \text { years of age; } \\
\text { insulin }\end{array}$ & $\begin{array}{l}\text { Hypothyroid at } 36 \\
\text { years; thyroxine }\end{array}$ & $\begin{array}{l}\text { Pernicious anaemia } \\
\text { (for } 2 \text { years); } \\
\text { hysterectomy }\end{array}$ & $\begin{array}{l}51 \text { years; red, } \\
\text { watery eyes } \\
\text { (18 months), } \\
\text { diplopia ( } 8 \text { months), } \\
\text { obscurations } \\
\text { (1 month) }\end{array}$ & $\begin{array}{l}\text { Acuity } 6 / 12 \text { right, } 6 / 9 \text { left; no } \\
\text { RAPD, tight orbits and fair } \\
\text { EOM, episcleral venous } \\
\text { engorgement, markedly } \\
\text { raised intraocular pressures, } \\
\text { Hertel } 26 \mathrm{~mm} \text { right, } 27 \mathrm{~mm} \text { left } \\
\text { orbit, gross right, moderate } \\
\text { left disc swelling }\end{array}$ \\
\hline 4 (Female) & $\begin{array}{l}63 \text { years of age; } \\
\text { metformin }\end{array}$ & $\begin{array}{l}\text { Thyrotoxic at } 64 \\
\text { years; carbimazole }\end{array}$ & $\begin{array}{l}\text { Sickle cell trait; } \\
\text { Hypertension }\end{array}$ & $\begin{array}{l}66 \text { years; watery } \\
\text { eyes ( } 10 \text { months), } \\
\text { decreasing vision } \\
(2 \text { months), } \\
\text { obscurations } \\
\text { ( } 2 \text { months) }\end{array}$ & $\begin{array}{l}\text { Acuity CF right, } 6 / 24 \text { left; no } \\
\text { RAPD, tight orbits and fair } \\
\text { EOM, episcleral venous } \\
\text { engorgement, normal } \\
\text { intraocular pressures, Hertel } \\
23 \text { mm right, } 22 \text { mm left orbit, } \\
\text { mild bilateral optic disc } \\
\text { swelling and left disc } \\
\text { collaterals (previous left vein } \\
\text { occlusion) }\end{array}$ \\
\hline 5 (Female) & $\begin{array}{l}34 \text { years of age; } \\
\text { insulin }\end{array}$ & $\begin{array}{l}\text { Hypothyroid at } 38 \\
\text { years; thyroxine }\end{array}$ & $\begin{array}{l}\text { Splenectomy for } \\
\text { thrombocytopaenia; } \\
\text { hypertension }\end{array}$ & $\begin{array}{l}63 \text { and } 65 \text { years; red, } \\
\text { irritable eyes } \\
\text { ( } 6 \text { months), } \\
\text { decreased right } \\
\text { vision ( } 2-3 \text { months), } \\
\text { obscurations right } \\
\text { eye ( } 6 \text { weeks) }\end{array}$ & $\begin{array}{l}\text { Acuity } 6 / 36 \text { right, } 6 / 9 \text { left; } \\
\text { moderate right RAPD, fair } \\
\text { EOM each eye, gross } \\
\text { episcleral venous } \\
\text { engorgement, markedly } \\
\text { raised intraocular pressures, } \\
\text { Hertel } 22 \text { mm each orbit, gross } \\
\text { right disc swelling, macular } \\
\text { oedema and choroidal folds; } \\
\text { left fundus normal }\end{array}$ \\
\hline 6 (Female) & None & $\begin{array}{l}\text { Thyrotoxic at } 52 \\
\text { years; carbimazole }\end{array}$ & None & $\begin{array}{l}53 \text { years; swollen } \\
\text { lids ( } 1 \text { year), } \\
\text { decreasing vision } \\
\text { ( } 8 \text { months), } \\
\text { obscurations } \\
\text { ( } 2 \text { months) }\end{array}$ & $\begin{array}{l}\text { Acuity } 6 / 9 \text { right, } 6 / 9 \text { left; no } \\
\text { RAPD, tight orbits and fair } \\
\text { EOM, gross episcleral venous } \\
\text { engorgement, moderately } \\
\text { raised intraocular pressures, } \\
\text { Hertel } 25 \text { mm each orbit, gross } \\
\text { disc swelling, with } \\
\text { peripapillary haemorrhages }\end{array}$ \\
\hline
\end{tabular}

RAPD denotes 'relative afferent pupillary defect'; EOM denotes extraocular movements.

Four patients required long-term topical therapy for control of intraocular pressures, although in all cases fewer medications were required and pressure was better controlled than before surgery (to within normal range).
Two patients required bilateral strabismus surgery for exacerbation of esotropia that had been present before decompression, with restoration of a good field of binocular single vision. 
Table 2 Details of patients undergoing orbital decompression for visual obscurations due to 'hydraulic' thyroid eye disease

\begin{tabular}{|c|c|c|c|c|}
\hline $\begin{array}{l}\text { Patient } \\
\text { number }\end{array}$ & $\begin{array}{l}\text { Systemic treatment } \\
\text { for thyroid eye } \\
\text { disease }\end{array}$ & $\begin{array}{l}\text { Age at orbital } \\
\text { decompression }\end{array}$ & Final visual functions & $\begin{array}{l}\text { Subsequent ophthalmic } \\
\text { treatment }\end{array}$ \\
\hline 1 (Male) & $\begin{array}{l}\text { Prednisolone and } \\
\text { methotrexate }\end{array}$ & $\begin{array}{l}43 \text { years; } \\
\text { bilateral 3-wall }\end{array}$ & $\begin{array}{l}\text { Acuity } 6 / 5 \text { right, } 6 / 6 \text { left; no RAPD, no } \\
\text { visual obscurations, normal intraocular } \\
\text { pressures and optic discs, Hertel } 17 \mathrm{~mm} \\
\text { each orbit }\end{array}$ & $\begin{array}{l}\text { Bilateral strabismus } \\
\text { surgery }\end{array}$ \\
\hline 2 (Female) & $\begin{array}{l}\text { Prednisolone and } \\
\text { methotrexate }\end{array}$ & $\begin{array}{l}51 \text { years; } \\
\text { bilateral 3-wall }\end{array}$ & $\begin{array}{l}\text { Acuity } 6 / 9 \text { right, } 6 / 12 \text { left (Herpetic } \\
\text { keratitis), RAPD unassessable (miosis), } \\
\text { no visual obscurations, intraocular } \\
\text { pressures controlled on drops, normal } \\
\text { optic discs, Hertel } 20 \mathrm{~mm} \text { right, } 19 \mathrm{~mm} \\
\text { left orbit }\end{array}$ & $\begin{array}{l}\text { Topical medication for } \\
\text { IOP control, topical } \\
\text { therapy for chronic left } \\
\text { kerato-uveitis }\end{array}$ \\
\hline 3 (Female) & $\begin{array}{l}\text { Prednisolone and } \\
\text { methotrexate }\end{array}$ & $\begin{array}{l}51 \text { years; } \\
\text { bilateral medial } \\
\text { wall and floor }\end{array}$ & $\begin{array}{l}\text { Acuity } 6 / 12 \text { right (vitreous haem), } 6 / 9 \\
\text { left; no RAPD, no visual obscurations, } \\
\text { intraocular pressures controlled on } \\
\text { drops, normal optic discs; regressed } \\
\text { right disc new vessels and right macular } \\
\text { oedema, Hertel } 20 \mathrm{~mm} \text { right, } 21 \mathrm{~mm} \text { left } \\
\text { orbit }\end{array}$ & $\begin{array}{l}\text { Topical medication for } \\
\text { IOP control }\end{array}$ \\
\hline 4 (Female) & $\begin{array}{l}\text { Prednisolone and } \\
\text { mycophenylate }\end{array}$ & $\begin{array}{l}66 \text { years; } \\
\text { bilateral 3-wall }\end{array}$ & $\begin{array}{l}\text { Acuity } 6 / 6 \text { right, } 6 / 9 \text { left; no RAPD, no } \\
\text { visual obscurations, intraocular } \\
\text { pressures controlled on drops, normal } \\
\text { optic discs; left collaterals, Hertel } 20 \mathrm{~mm} \\
\text { each orbit }\end{array}$ & $\begin{array}{l}\text { Topical medication for } \\
\text { IOP control, right } \\
\text { cataract surgery }\end{array}$ \\
\hline 5 (Female) & Prednisolone & $\begin{array}{l}63 \text { years; right } \\
\text { medial wall and } \\
\text { floor, } 65 \text { years; } \\
\text { Left medial wall } \\
\text { and floor }\end{array}$ & $\begin{array}{l}\text { Acuity } 6 / 9 \text { right, } 6 / 9 \text { left; no RAPD, No } \\
\text { visual obscurations, Persistent episcleral } \\
\text { vascular engorgement, Intraocular } \\
\text { pressures controlled on drops, Slight } \\
\text { right optic atrophy; normal left disc, } \\
\text { Hertel } 14 \mathrm{~mm} \text { right, } 15 \mathrm{~mm} \text { left orbit }\end{array}$ & $\begin{array}{l}\text { Topical medication for } \\
\text { IOP control }\end{array}$ \\
\hline 6 (Female) & $\begin{array}{l}\text { Prednisolone; } \\
\text { orbital } \\
\text { radiotherapy }\end{array}$ & $\begin{array}{l}53 \text { years; } \\
\text { bilateral 3-wall }\end{array}$ & $\begin{array}{l}\text { Acuity } 6 / 6 \text { right, } 6 / 6 \text { left; no RAPD, No } \\
\text { visual obscurations, Normal intraocular } \\
\text { pressures and optic discs, Hertel } 17 \mathrm{~mm} \\
\text { each orbit }\end{array}$ & $\begin{array}{l}\text { Bilateral strabismus } \\
\text { surgery }\end{array}$ \\
\hline
\end{tabular}

Table 3 Manometric pressures within the posterior part of the orbit in patients with and without (inactive) thyroid eye disease: The figures record the mean pressure rise immediately after retrobulbar injection of $1.66,3.33$ and $5.0 \mathrm{ml}$ of fluid, together with the pressure 5 min after last injection of fluid (mean \pm SD)

\begin{tabular}{|c|c|c|c|c|c|c|}
\hline Group size & $\begin{array}{l}\text { Baseline } \\
(\mathrm{mmHg})\end{array}$ & $\begin{array}{c}\text { Pressure after } \\
\text { injection } 1.66 \mathrm{ml}\end{array}$ & $\begin{array}{c}\text { Pressure after } \\
\text { injection } 3.33 \mathrm{ml}\end{array}$ & $\begin{array}{l}\text { Pressure after } \\
\text { injection } 5 \mathrm{ml}\end{array}$ & $\begin{array}{l}\text { Pressure } 5 \text { min after } \\
\text { last injection }\end{array}$ & $\begin{array}{l}\text { Orbital compliance } \\
(\mathrm{ml} / \mathrm{mmHg})\end{array}$ \\
\hline $\begin{array}{l}\text { Control orbits } \\
\text { (35 patients) }\end{array}$ & 4.4 & 6.6 & 9.2 & 12.0 & 6.7 & $0.80 \pm 0.50$ \\
\hline $\begin{array}{l}\text { Thyroid orbits } \\
\text { (18 patients) }\end{array}$ & 9.7 & 14.7 & 20.1 & 36.3 & 13.7 & $0.27 \pm 0.21$ \\
\hline
\end{tabular}

The orbits of patients with prior thyroid eye disease show a significantly greater rise in pressure with retrobulbar injection and the calculated orbital tissue compliance is significantly lower in these patients (derived from Riemann, Foster and Kosmorsky').

\section{Discussion}

Thyroid-related orbital inflammation leads to vasodilatation, leakage of intravascular fluid into the tissue and increasing orbital tissue pressure, especially within the confines of the orbital apex. ${ }^{1,2}$ Deposition of extra ground substances (glycosaminoglycans; GAGs) within orbital tissues, together with post-inflammatory fibrosis, decreases tissue compliance-as has been eloquently demonstrated with in vivo manometry ${ }^{9}$ (Table 3). This decreased compliance - particularly when coupled with an unyielding orbital septum that prevents proptosis - might result in a sustained rise in orbital pressure, decreased tissue perfusion and impairing optic 


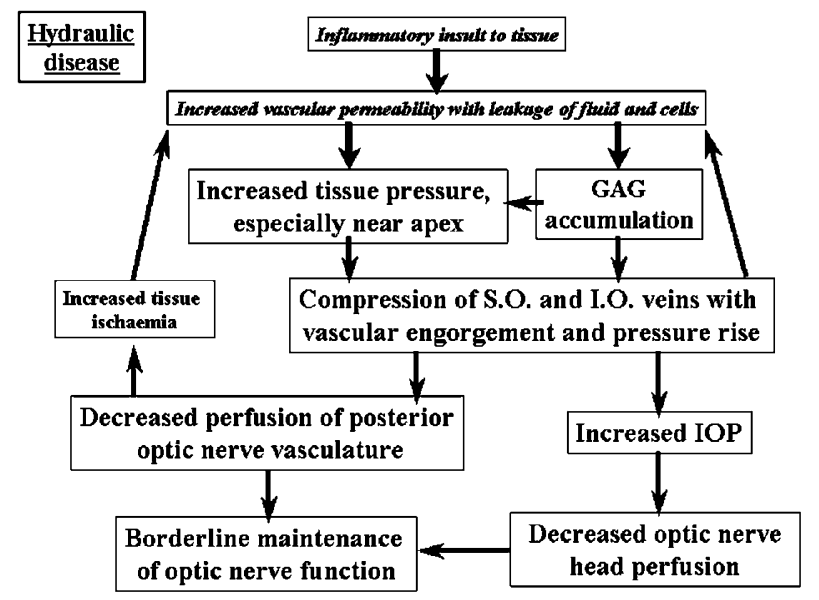

Figure 6 Diagrammatic representation of the orbital tissue changes in thyroid eye disease: 'Hydraulic', or 'meta-active', disease occurs when the pressure within the orbital tissues and vasculature remains persistently raised after the acute inflammatory phase (in italics) has settled. ('S.O. and I.O. veins' denote 'superior ophthalmic and inferior ophthalmic veins').

nerve function; there being a recognised inverse relationship between the degree of proptosis and the tendency to thyroid optic neuropathy. The tendency to optic neuropathy might be greater in Asian patients, in whom the orbital septum is less compliant and the orbital apex more confined by thick bone. ${ }^{7,8}$

Some patients with high orbital pressures do not have overt optic neuropathy, but instead develop a marked episcleral venous congestion - resembling the arteriolised vessels of low-flow dural shunts - with chronically raised intraocular pressures, often on multiple therapy (Figure 1b). These clinical signs are frequently misinterpreted as active orbital inflammation, although this late, congestive phase of orbitopathy is well beyond the stage of active inflammation; this late stage being termed 'hydraulic' or 'meta-active' disease by the writer (Figure 6), thereby differentiating it from the acute congestion of active inflammation.
Among patients with meta-active, hydraulic disease, there appear some with borderline optic nerve perfusion - a blood flow that is only just able to maintain neuronal function (Figure 6). Such patients would seem to be liable to visual obscuration whenever there is a fall in systemic blood pressure due to postural change, diabetics appearing particularly susceptible to this phenomenon (Table 1). In all of these patients, the high orbital tissue pressure was associated with marked optic disc swelling (Figures $3 b$ and $5 b$ ) — this suggesting a peripapillary vasculopathy, similar to diabetic papillopathy. The vascular embarrassment of the optic nerve (due to high intraorbital pressure) is very effectively relieved by orbital decompression and leads to an immediate cessation of postural visual obscurations.

\section{References}

1 Kennerdell JS, Rosenbaum AE, El-Hoshy MH. Apical optic nerve compression of dysthyroid optic neuropathy on computed tomography. Arch Ophthalmol 1988; 99: 807-809.

2 Neigel JM, Rootman J, Belkin RI, Nugent RA, Drance SM, Beattie CW et al. Dysthyroid optic neuropathy, the crowded orbital apex syndrome. Ophthalmology 1988; 95: 1515-1521.

3 Lucarelli MJ, Shore JW. Management of thyroid optic neuropathy. Int Ophthalmol Clin 1996; 36: 179-193.

4 Goldberg RA. The evolving paradigm of orbital decompression surgery. Arch Ophthalmol 1998; 116: 95-96.

5 Siracuse-Lee DE, Kazim M. Orbital decompression: current concepts. Curr Opin Ophthalmol 2002; 13: 310-316.

6 Nugent RA, Belkin RI, Neigel JM, Rootman J, Robertson WD, Spineui J et al. Graves' orbitopathy: correlation of CT and clinical findings. Radiology 1990; 177: 675-682.

7 Rootman J. Aspects of current management of thyroid orbitopathy in Asians. Asia Pac J Ophthalmol 1998; 10: 2-6.

8 Liao SL, Kao SCS, Hou PK, Chen MS. Results of orbital decompression in Taiwan. Orbit 2001; 20: 267-274.

9 Riemann CD, Foster JA, Kosmorsky GS. Direct orbital manometry in patients with thyroid-associated orbitopathy. Ophthalmology 1999; 106: 1296-1302. 